\title{
Retinol binding protein 3 as biomarker for diabetic retinopathy
}

\author{
Ward Fickweiler ${ }^{1,2}$, Lloyd P. Aiello ${ }^{1,2,3}$, Jennifer K. Sun ${ }^{1,2,3}$, George L. King ${ }^{1,3,4}$ \\ ${ }^{1}$ Research Division, ${ }^{2}$ Beetham Eye Institute, Joslin Diabetes Center, Boston, MA, USA; ${ }^{3}$ Department of Ophthalmology, ${ }^{4}$ Department of Medicine, \\ Harvard Medical School, Boston, MA, USA \\ Correspondence to: George L. King, MD. Research Division, Joslin Diabetes Center, One Joslin Place, Boston, MA 02215, USA. \\ Email: george.king@joslin.harvard.edu. \\ Provenance: This is an invited article commissioned by the Section Editor Dr. Wan Wang (Medical Technology School, Xuzhou Medical University, \\ Xuzhou, China). \\ Response to: Rusciano D, Bagnoli P. RBP3: a possible prognostic marker and therapeutic target in diabetic retinopathy. Ann Transl Med 2019. doi: \\ 10.21037/atm.2019.09.133
}

Submitted Oct 01, 2019. Accepted for publication Oct 22, 2019.

doi: $10.21037 / \mathrm{atm} .2019 .10 .95$

View this article at: http://dx.doi.org/10.21037/atm.2019.10.95

We thank Dr. Rusciano and Dr. Bagnoli for their interest in our article "Retinol binding protein 3 is increased in the retina of patients with diabetes resistant to diabetic retinopathy" (1). Our article identified the first neuroretinal selective protein to act on retinal vasculature, suggesting numerous therapeutic and diagnostic possibilities. Several reports have suggested potential circulatory biomarkers which may be associated with severity of diabetic retinopathy (DR) (2-10). However, a major limiting factor in those studies is that the expression of those factors is not limited to the retina and are generally primarily expressed in other tissues. Thus, the circulating levels of those factors do not specifically represent retinal changes. However, $\mathrm{RBP} 3$ is very selectively expressed in the photoreceptors of the retina, with only very minor expression in the pineal gland. With the development of a highly sensitive and selective ELISA, we can measure RBP3 in the vitreous and accessible human fluids including the serum. Future studies are needed to elucidate the utility of circulating RBP3 levels as a biomarker for the severity or potential progression of DR.

\section{Acknowledgments}

None.

\section{Footnotes}

Conflicts of Interest: The authors have no conflicts of interest to declare.

Ethical Statement: The authors are accountable for all aspects of the work in ensuring that questions related to the accuracy or integrity of any part of the work are appropriately investigated and resolved.

\section{References}

1. Yokomizo H, Maeda Y, Park K, et al. Retinol binding protein 3 is increased in the retina of patients with diabetes resistant to diabetic retinopathy. Sci Transl Med 2019;11. doi: 10.1126/scitranslmed.aau6627.

2. Choudhuri S, Dutta D, Sen A, et al. Role of N-epsiloncarboxy methyl lysine, advanced glycation end products and reactive oxygen species for the development of nonproliferative and proliferative retinopathy in type 2 diabetes mellitus. Mol Vis 2013;19:100-13.

3. Sun JK, Keenan HA, Cavallerano JD, et al. Protection from retinopathy and other complications in patients with type 1 diabetes of extreme duration: the joslin 50-year medalist study. Diabetes Care 2011;34:968-74.

4. Lee IK, Park KY, Oh HK, et al. Plasma type IV collagen and fibronectin concentrations in diabetic patients with microangiopathy. J Korean Med Sci 1994;9:341-6.

5. Hernandez SL, Gong JH, Chen L, et al. Characterization of circulating and endothelial progenitor cells in patients with extreme-duration type 1 diabetes. Diabetes Care 2014;37:2193-201. 


\section{Page 2 of 2}

6. Schram MT, Chaturvedi N, Schalkwijk CG, et al. Markers of inflammation are cross-sectionally associated with microvascular complications and cardiovascular disease in type 1 diabetes--the EURODIAB Prospective Complications Study. Diabetologia 2005;48:370-8.

7. Roy MS, Janal MN, Crosby J, et al. Inflammatory biomarkers and progression of diabetic retinopathy in African Americans with type 1 diabetes. Invest Ophthalmol Vis Sci 2013;54:5471-80.

8. van Hecke MV, Dekker JM, Nijpels G, et al.

Cite this article as: Fickweiler W, Aiello LP, Sun JK, King GL. Retinol binding protein 3 as biomarker for diabetic retinopathy. Ann Transl Med 2019;7(22):706. doi: 10.21037/atm.2019.10.95
Fickweiler et al. Retinol binding protein 3 in diabetic eye disease

Inflammation and endothelial dysfunction are associated with retinopathy: the Hoorn Study. Diabetologia 2005;48:1300-6.

9. Simo-Servat O, Simo R, Hernandez C. Circulating Biomarkers of Diabetic Retinopathy: An Overview Based on Physiopathology. J Diabetes Res 2016;2016:5263798.

10. Lim LS, Tai ES, Mitchell P, et al. C-reactive protein, body mass index, and diabetic retinopathy. Invest Ophthalmol Vis Sci 2010;51:4458-63. 